\title{
Argyrophilic nucleolar organizer regions (AgNORs) in interphases and metaphases of normal and neoplastic gill cells of Macoma balthica (Bivalvia: Tellinidae) from the Gulf of Gdansk, Baltic Sea
}

\author{
K. Smolarz ${ }^{1}$, M. Wolowicz ${ }^{1}$, C. Thiriot-Quiévreux ${ }^{2, *}$ \\ ${ }^{1}$ Laboratory of Estuarine Ecology, Institute of Oceanography, University of Gdansk, Al. Marszalka, J. Pilsudskiego, \\ 81-378 Gdynia, Poland \\ ${ }^{2}$ Observatoire Océanologique, UPMC, Centre National de la Recherche Scientifique, INSU, BP 28, \\ 06230 Villefranche-sur-Mer, France
}

\begin{abstract}
Chromosome analysis of gill cells of different populations of Macoma balthica (L.) from the Bay of Gdansk (Baltic Sea) revealed 2 clam categories, 1 with neoplastic features and 1 without. Silver-staining was performed on interphase and metaphase cells of both categories. The mean argyrophilic nucleolar organizer region (AgNOR) count per abnormal interphase cell was significantly higher than in normal interphase cells. Normal silver-stained metaphases had 3 nucleolar organizer region (NOR) chromosome phenotypes. The location of the NORs in the most frequent phenotype (55.6\% in 54 metaphases scored) was interstitial on the largest metacentric chromosome pair, Pair No. 1. Abnormal silver-stained metaphases had a higher number of active NOR sites. Different phenotypes were observed (frequency greater than $10 \%$ for 67 metaphases scored); 2 were similar to those in normal metaphases and 5 were ectopic. The higher activity of AgNORs observed in abnormal cells confirmed the diagnosis of malignant neoplasia.
\end{abstract}

KEY WORDS: Silver-staining $\cdot$ Nucleolar organizer regions $\cdot$ Neoplasia $\cdot$ Macoma balthica $\cdot$ Baltic Sea

\section{INTRODUCTION}

Disseminated neoplasia have been described for several bivalve species from different geographical origins (see Elston et al. 1992 and Peters et al. 1994 for reviews, and recent papers of Alonso et al. 2001 and Villaba et al. 2001). In the Baltic clam Macoma balthica (L.), a gill-originating neoplasia has been reported (e.g. Pekkarinen 1993). Chromosome analyses based on Giemsa-stained metaphases of gill tissue from different populations of $M$. balthica from the Gulf of Gdansk revealed 2 clam categories, 1 with a diploid chromosome number of 38 , and 1 displaying hyperploidy and chromosomal abnormalities related to neoplasia. The prevalence of affected clams varied from 0 to $94 \%$ at the different sites studied (Thiriot-Quiévreux \& Wolowicz 1996, 2001).

Further investigations on the cytogenetic characterization of these 2 clam categories were carried out in the present study using silver-staining.

The importance of the analysis of silver-stained nucleolar organizer regions (AgNORs) for prognosis in tumor pathology has been reviewed by Pich et al. (2000). Interphase AgNORs are structural units of the nucleolus in which all the components necessary for ribosomal RNA synthesis are located (see Derenzini 2000 for review literature). The number of interphase AgNORs per cell reflects the proliferative activity in tumor cells (e.g. Trerè 2000, Zergeroglu et al. 2001). Counts of interphase AgNORs have also been used for 
the determination of ploidy level of different species (e.g. Phillips et al. 1986, Lozano et al. 1992, Kucharczyk et al. 1997, Okumara et al. 2001).

Silver-staining of mitotic metaphases also allows detection of the specific chromosome sites of AgNORs that were active at the previous interphase (e.g. Howell 1977, Hubbel 1985). For example, data have been given on the number and the chromosomal location of AgNORs in metaphases of several bivalve species (see Thiriot-Quiévreux 2002 for review). Reports on AgNORs in tumor metaphases are rare, although chromosomes bearing ectopic AgNORs have been observed in human tumors (e.g. DeLozier-Blanchet et al. 1986, Neerman-Arbez et al. 1993, Atkin \& Baker 1995, Blough et al. 1998).

The aim of this work was to investigate AgNORs in interphase and metaphase gill cells from affected and non-affected Macoma balthica to better elucidate the cytogenetic features of neoplasia in this species.

\section{MATERIALS AND METHODS}

Specimens of Macoma balthica were collected by dredging at 4 localities in the Gulf of Gdansk (Baltic Sea). Clams from 8 to $23 \mathrm{~mm}$ in diameter were kept in the laboratory and fed for 3 to $4 \mathrm{~d}$ to promote somatic growth (thus increasing the mitotic index; Dixon \& Clarke 1982) and to decrease any stress reaction. Because we were working only on somatic tissue taken from wild individuals, many non-affected clams were required to obtain a sufficient number of mitoses. The number of affected clams required was lower because these showed high proliferative activity.

Since cell-culture techniques are not yet available for molluscs, chromosome preparations were made from growing somatic tissue such as gills. Specimens of Macoma balthica were first incubated for $8 \mathrm{~h}$ in $0.005 \%$ colchicine in seawater in order to arrest mitosis at the metaphase. The gills were then dissected out and subjected to a hypotonic treatment of $0.9 \%$ solution of sodium citrate in distilled water for $45 \mathrm{~min}$. The material was then fixed in a freshly prepared solution of absolute ethanol-acetic acid (3:1) with 3 changes of 20 min each. Fixed pieces of gill from each individual were dissociated in $50 \%$ acetic acid with distilled water solution. The suspension was then dripped onto heated slides at $44^{\circ} \mathrm{C}$ and air-dried (Thiriot-Quiévreux \& Ayraud 1982). Silver-staining of nucleolar organizer regions (NORs) was performed at $44^{\circ} \mathrm{C}$ for $7 \mathrm{~min}$ on unstained slides with the 1-step

Table 1. Macoma balthica. Number of argyrophilic nucleolar organizers (AgNORs) per interphase cell ( $\mathrm{N}=100)$ in 10 nonaffected and 10 affected clams. CL: confidence limit

\begin{tabular}{|c|c|c|c|c|c|c|c|c|c|}
\hline \multirow[t]{2}{*}{ Clam no. } & \multicolumn{6}{|c|}{ No. of AgNORs cell ${ }^{-1}$} & \multirow[t]{2}{*}{ Mean } & \multirow[t]{2}{*}{$(\mathrm{SD})$} & \multirow[t]{2}{*}{$95 \% \mathrm{CL}$} \\
\hline & 0 & 1 & 2 & 3 & 4 & 5 & & & \\
\hline \multicolumn{10}{|c|}{ Non-affected } \\
\hline 1 & 2 & 52 & 44 & 2 & - & - & 1.47 & $(0.56)$ & \\
\hline 2 & 2 & 44 & 47 & 6 & 1 & - & 1.61 & $(0.65)$ & \\
\hline 3 & - & 48 & 46 & 6 & - & - & 1.57 & $(0.65)$ & \\
\hline 4 & 1 & 48 & 46 & 5 & - & - & 1.55 & $(0.61)$ & \\
\hline 5 & 1 & 69 & 30 & - & - & - & 1.31 & $(0.47)$ & \\
\hline 6 & - & 50 & 45 & 5 & - & - & 1.56 & $(0.59)$ & \\
\hline 7 & - & 46 & 51 & 1 & 2 & - & 1.59 & $(0.62)$ & \\
\hline 8 & - & 69 & 27 & 2 & 1 & 1 & 1.38 & $(0.68)$ & \\
\hline 9 & 2 & 47 & 44 & 4 & 3 & - & 1.57 & $(0.76)$ & \\
\hline 10 & - & 38 & 51 & 9 & 2 & - & 1.76 & $(0.7)$ & \\
\hline Total mean & & & & & & & 1.54 & $(0.64)$ & $1.50-1.58$ \\
\hline \multicolumn{10}{|l|}{ Affected } \\
\hline 1 & - & 40 & 22 & 28 & 8 & 2 & 2.1 & $(1.08)$ & \\
\hline 2 & - & 36 & 34 & 22 & 7 & 1 & 2.04 & (0.97) & \\
\hline 3 & - & 21 & 31 & 36 & 12 & - & 2.41 & $(0.94)$ & \\
\hline 4 & - & 10 & 29 & 30 & 24 & 7 & 2.91 & $(1.10)$ & \\
\hline 5 & - & 10 & 19 & 41 & 24 & 6 & 3.00 & (1.04) & \\
\hline 6 & - & 15 & 33 & 37 & 12 & 3 & 2.56 & (0.99) & \\
\hline 7 & - & 25 & 20 & 37 & 14 & 4 & 2.51 & (1.14) & \\
\hline 8 & - & 20 & 39 & 31 & 8 & 2 & 2.36 & $(0.95)$ & \\
\hline 9 & - & 15 & 23 & 45 & 11 & 6 & 2.70 & (1.05) & \\
\hline 10 & - & 12 & 26 & 44 & 16 & 2 & 2.70 & $(0.95)$ & \\
\hline Total mean & & & & & & & 2.53 & $(1.06)$ & $2.47-2.56$ \\
\hline
\end{tabular}


method of Howell \& Black (1980), which combines a colloidal developer and an aqueous silver nitrate solution. Ag-stained slides were scored by microscope observation. Photographs of nucleoli and suitable well-spread mitoses were taken with a Zeiss III photomicroscope.

The number of nucleoli, visible as AgNOR dots in the nuclei, were counted in 100 interphase cells per individual in 10 affected and 10 non-affected clams. Basic statistic analyses were made using ANOVA.

Non-affected clams only had metaphases with a diploid number of chromosomes $(2 \mathrm{n}=38$ in Macoma balthica), whereas affected clams contained a proliferation of abnormal metaphases with hyperploidy and chromosomal abnormalities related to neoplasia (Thiriot-Quiévreux \& Wolowicz 1996, 2001). Positive AgNORs were recorded in 54 metaphases from 24 non-affected clams and in 67 metaphases taken from 9 affected clams.

\section{RESULTS}

The distribution of cells with different numbers of nucleoli per interphase $(\mathrm{N}=100$, in 10 non-affected and 10 affected clams) is shown in Table 1 . The mean number of nucleoli in normal interphases was 1.54, with $95 \%$ confidence limits of 1.50 to 1.58 . In most cases 1 or 2 nucleoli per nucleus were present
(Fig. 1A), although occasionally more than 2 nucleoli were also observed. The mean number of nucleoli per cell in abnormal interphases was 2.53 with confidence limits of 2.47 to 2.56 . In most cases 2,3 or 4 nucleoli were present, with a maximum of 5 nucleoli per interphase cell (Fig. 1B). There was a significant difference $(\mathrm{p}<0.0001)$ in the AgNOR counts between normal and abnormal interphase cells. Moreover, the size of the abnormal interphase cells and their nucleoli was much larger (cf. interphase cells in Figs. 2A \& 3).

AgNORs were examined in 54 normal metaphases and karyotypes were made from 12 well-spread metaphases (Fig. 2). Chromosome pairs were classified (11 metacentric, 2 submetacentric, 6 subtelocentric) according to the pattern described by ThiriotQuiévreux \& Wolowicz (1996). Table 2 summarizes the AgNOR results. A variable number of AgNOR chromosomes were observed within and between individuals. The most frequent phenotype (A) $(55.6 \%)$ was heterozygous and interstitially located on the largestsized metacentric chromosome pair, Pair No. 1. Another phenotype (B: terminal on a large-sized metacentric chromosome pair, Pair No. 4) was also observed, but was less frequent $(12.96 \%)$. Phenotype $\mathrm{C}$ (terminal on a long arm of a medium-sized subtelocentric chromosome) was scored simultaneously with either Phenotype A (11\%) or B (11\%) in the same metaphase. The frequency of AgNORs comprising $<10 \%$ was not taken into account.

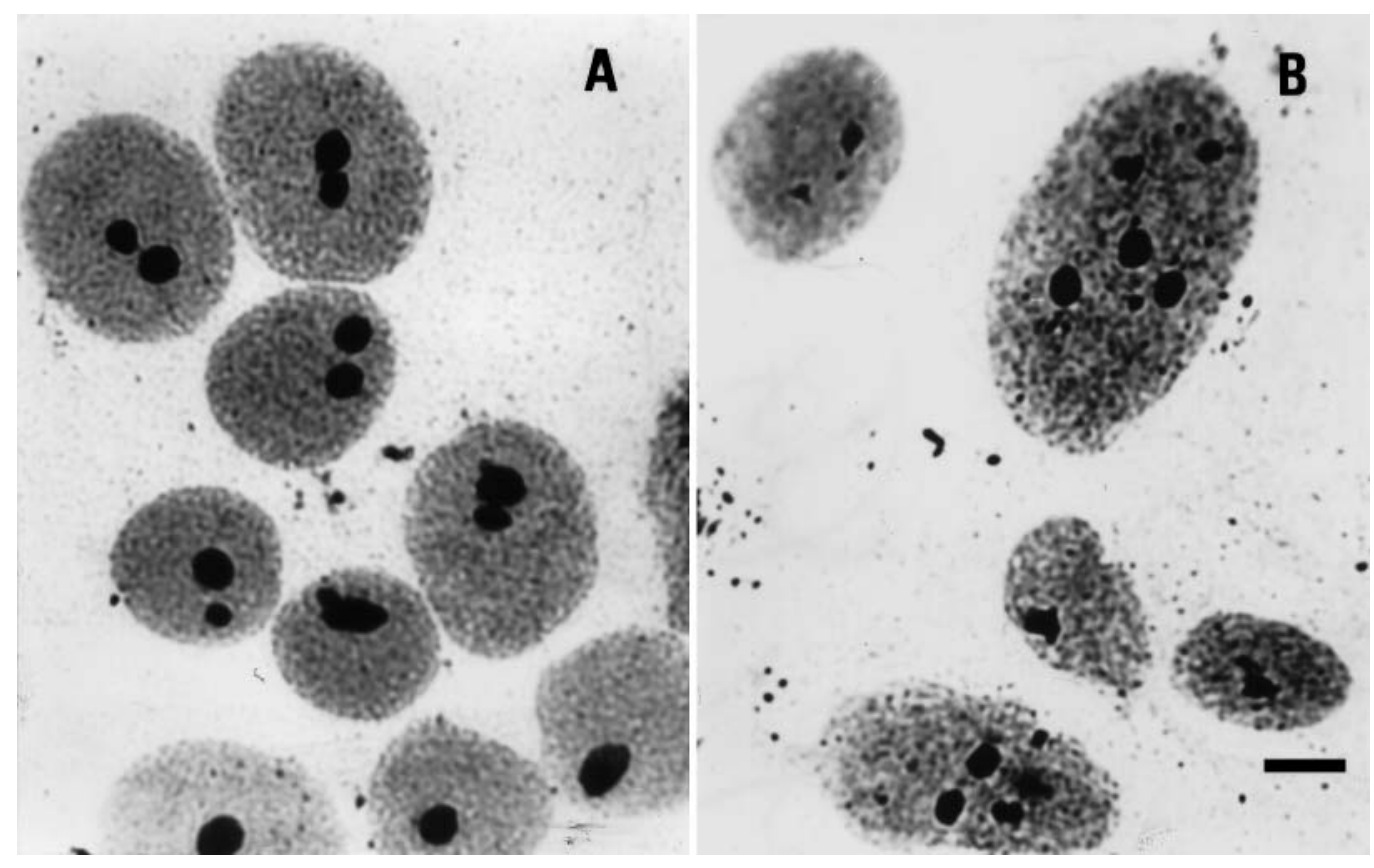

Fig. 1. Macoma balthica. Silver-stained normal interphase cells (A) and abnormal interphase cells (B) in gills. Scale bar (valid for $A$ and $B)=5 \mu \mathrm{m}$ 


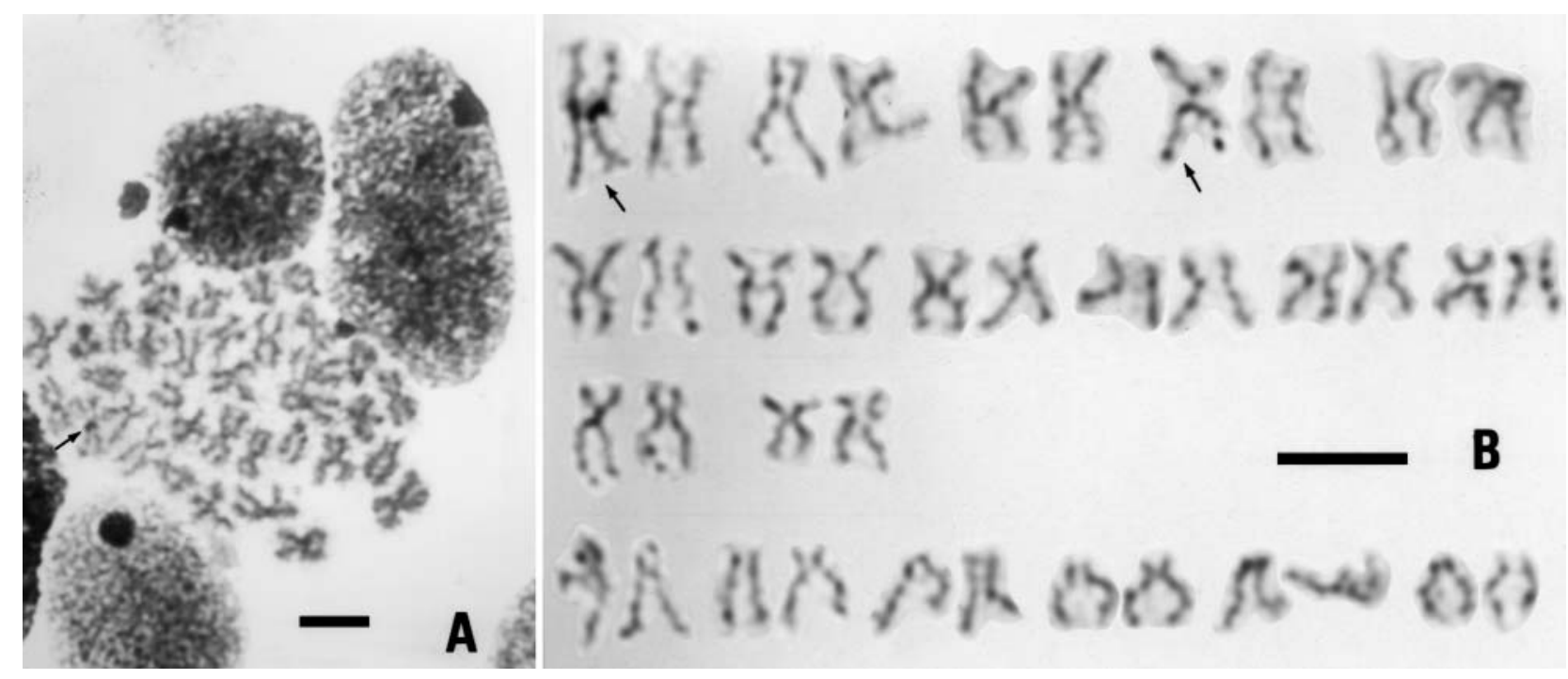

Fig. 2. Macoma balthica. (A) Silver-stained normal metaphase in gills; (B) silver-stained karyotype of a metaphase. Arrows indicate argyrophilic nucleolar organizers (AgNORs). Scale bars $=5 \mu \mathrm{m}$

AgNOR activity was also analyzed in 67 abnormal metaphases of 9 affected clams (Fig. 3). None of these displayed a consistent number of AgNORs per cell, and there was a variable number of 1 to 5 AgNOR positive chromosomes within and between clams. Different phenotypes (A to $H$ ) were observed in the same metaphases. Phenotypes A and B correspond to those of normal metaphases and D to $\mathrm{H}$ are ectopic. Because of the variable number of NOR-bearing chromosomes

Table 2. Macoma balthica. Summary of major argyrophilic nucleolar organizer region (AgNOR) observations (frequency $>10 \%$ ) in metaphase cells. Phenotype A: interstitial on large-sized metacentric; B: terminal on large-sized metacentric pair; C: terminal on long arm of medium-sized subtelocentric. Ectopic phenotypes $=\mathrm{D}$ : terminal on a medium-sized metacentric; E: terminal on long arm of medium-sized telocentric; F: intersitial on medium-sized metacentric; G: terminal on short arm of large-sized submetacentric; H: terminal on short arm of medium-sized submetacentric

\begin{tabular}{|lccc|}
\hline $\begin{array}{l}\text { No. of Ag-stained } \\
\text { metaphases }\end{array}$ & $\begin{array}{c}\text { No. of haploid } \\
\text { chromosomes }\end{array}$ & $\begin{array}{c}\text { Chromosome } \\
\text { phenotype }\end{array}$ & $\begin{array}{c}\text { Frequency } \\
\text { (\%) }\end{array}$ \\
\hline $\begin{array}{l}\text { Normal } \\
30\end{array}$ & 1 & & \\
7 & 1 & A & 55.6 \\
6 & 2 & B & 12.96 \\
6 & 2 & B, C & 11.11 \\
Abnormal & & A, C & 11.11 \\
33 & $2-5$ & & \\
18 & $2-5$ & D & 49.25 \\
17 & $2-4$ & B & 26.87 \\
14 & $1-3$ & E & 25.37 \\
14 & $1-4$ & A & 20.9 \\
11 & $1-4$ & G & 20.9 \\
10 & $2-4$ & H & 16.42 \\
& & & 14.93 \\
\hline
\end{tabular}

among metaphases, the frequency of each phenotype was calculated by scoring its occurrence in all metaphases studied $(\mathrm{N}=67)$ (Table 2). The most frequent active phenotype was the ectopic phenotype D $(49.25 \%)$. The activity of other AgNOR-positive phenotypes, already described in normal metaphases (i.e. A and B) was lower (20.9 and $26.87 \%$ respectively). Phenotype $\mathrm{C}$ was also scored simultaneously with other ectopic phenotypes at a lower frequency $(7.46 \%)$, and 4 other ectopic phenotypes $(E, F, G$ and $H)$ were also observed at lower frequencies (25.37 to $14.93 \%)$. Intra- and interindividual heteromorphism was observed in all AgNOR phenotypes, as in normal metaphases.

\section{DISCUSSION}

The data currently available in literature demonstrate that the number of interphase AgNORs is an independent prognostic factor in several types of human tumors (e.g. Pich et al. 1995, 2000, 2002). Our results on the comparison of AgNOR counts in interphase cells of the clam Macoma balthica revealed a significant difference between affected and non-affected individuals. The lowest mean AgNOR score (1.54) was found in normal and the highest (2.53) in abnormal inter- 


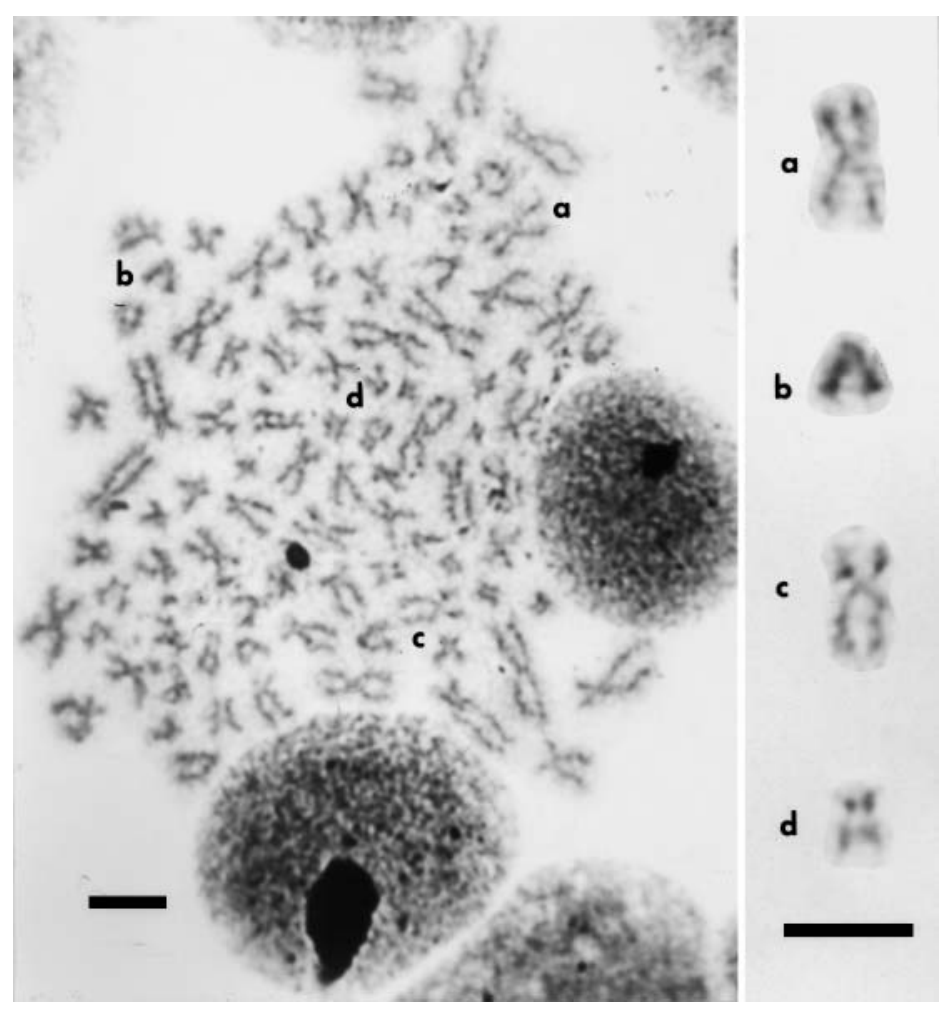

Fig. 3. Macoma balthica. Silver-stained abnormal metaphase in gills; 4 AgNOR phenotypes (see Table 2) are shown at higher magnification on the right. $a$, Phenotype $D_{;} b$, Phenotype $E_{;} c$, Phenotype $F_{;} d$, Phenotype $\mathrm{H}$. Scale bars $=5 \mu \mathrm{m}$ metaphases, the remainder being ectopic. Therefore, as in interphase cells, the comparison of AgNOR patterns in normal and abnormal metaphase cells revealed a strong increase of AgNOR sites in neoplastic animals. Chromosomes bearing ectopic AgNORs have been described in human tumors (e.g. DeLozierBlanchet et al. 1986, Neerman-Arbez et al. 1993, Atkin \& Baker 1995, Blough et al. 1998). Ectopic NORs could derive from constitutional double NORs, and the presence of ectopic NORs seems to reflect the multiplicity of structural changes in tumors (Atkin \& Baker 1995). In the case of $M$. balthica, the observed chromosome aberrations involved numerical and structural abnormalities, but no marker chromosomes were identified (Thiriot-Quiévreux \& Wolowicz 1996, 2001). Even if chromosomes bearing ectopic AgNORs can be considered marker chromosomes, their implication in neoplastic structural changes cannot be specified because of the absence of individual chromosome identification in these metaphases.

In conclusion, our results on the silver-staining of AgNORs in interphases and metaphases of normal and abnormal gill cells of Macoma balthica revealed a higher level of AgNOR activity in affected clams and confirmed the diagnosis of neoplasia. phase cells. The high AgNOR quantity in interphase gill cells of affected clams implied a prognostic function for malignant tumors (Pich et al. 2000).

Patterns of AgNORs in normal metaphase cells of the bivalve Macoma balthica are reported here for the first time. We observed 3 NOR chromosome phenotypes. NOR-banded karyotypes revealed that the chromosomal location of $55.6 \%$ of the 54 scored metaphases was interstitial on the largest metacentric chromosome pair, Pair No. 1. This interstitial AgNOR chromosomal location is very rare in bivalves. Of the bivalve species in which silver-stained metaphases have been studied, only 1 species, Venerupis aurea, showed interstitial active AgNORs on a metacentric chromosome (Insua et al. 2001). Intra- and interindividual heteromorphism involving the number of AgNORs per metaphase, as observed in this study, has been detected in most bivalve species (Thiriot-Quiévreux 2002).

Abnormal silver-stained metaphases of Macoma balthica had a higher number of active NOR sites than normal ones. The observed number of active haploid NOR chromosomes (1 to 5 ) indicated a variable activity of NORs within and among individuals. Different phenotypes were detected, 2 being similar to normal
Acknowledgements. This study was supported by funds from the Polish-French Scientific and Technological Cooperation Joint Project 'Polonium' provided by the Committee of Scientific Research, Poland, and the Ministry for Foreign Affairs, France. We thank S. Sabini for excellent technical assistance and $\mathrm{H}$. McCombie for improving the English.

\section{LITERATURE CITED}

Alonso A, Suarez P, Alvarez C, San Juan F, Molist P (2001) Structural study of a possible neoplasia detected in Mytilus galloprovincialis collected from the Ria of Vigo (NW Spain). Dis Aquat Org 47:73-79

Atkin NB, Baker MC (1995) Ectopic nucleolar organizer regions. A common anomaly revealed by AgNOR staining of metaphases from nine cancers. Cancer Genet Cytogenet 85:129-132

Blough RI, Vance GH, Henegariu O, Smolarek TA, Sledge GW, Heerema NA (1998) Characterization of multiple 12p rearrangements in testicular germ cell tumor cell line $833 \mathrm{~K}$ and its subclone $64 \mathrm{CP}$ by chromosome microdissection. Cancer Genet Cytogenet 106:24-29

DeLozier-Blanchet CD, Walt H, Engel E (1986) Ectopic nucleolus organizer regions (NORs) in human testicular tumors. Cytogenet Cell Genet 41:107-113

Derenzini M (2000) The AgNORs. Micron 31:117-120

Dixon DR, Clarke KB (1982) Silver chromatid exchange: a sensitive method for detecting damage caused by expo- 
sure to environmental mutagens in the chromosome of adult Mytilus edulis. Mar Biol Lett 3:163-172

Elston RA, Moore JD, Brooks K (1992) Disseminated neoplasia of bivalve molluscs. Rev Aquat Sci 6:405-466

Howell WM (1977) Visualization of ribosomal gene activity; silver stains proteins with rRNA transcribed from oocyte chromosomes. Chromosoma 62:361-367

Howell WM, Black DA (1980) Controlled silver-staining of nucleolus organizer regions with a protective colloidal developer: a 1-step method. Experientia 36:1014-1015

Hubbel HR (1985) Silver staining as an indicator of active ribosomal genes. Stain Technol 60:285-294

Insua A, Freire R, Ríos A (2001) Localización cromosómica y patrones de variación de la DNA ribosómica en moluscos bivalvos. In: Méndez J (ed) Los moluscos bivalvos: aspectos citogenéticos, moleculares y aplicados. Universidade de Coruña, Servicio de Publicacións, Coruña, p 77-100

Kucharczyk D, Jankun M, Luczynski M (1997) Ploidy level determination in genetically manipulated bream, Abramis brama, based on the number of active nucleoli per cell. J Appl Aquacult 7:13-22

Lozano R, Ruiz-Rejon C, Ruiz Rejon M (1992) A comparative analysis of NORs in diploid and triploid salmonids: implications with respect to the diploidization process occurring in this fish group. Heredity 69:450-457

Neerman-Arbez M, DeLozier-Blanchet CD, Bolle JF, Rondez R, Morris M (1993) High incidence of ectopic nucleolar organizer regions in human testicular tumors. Cancer Genet Cyotgenet 65:58-63

Okumara SI, Furukawa S, Kawai T, Takahashi S, Yamamori K (2001) Comparison of nucleoli number in diploid and triploid larva of Pacific abalone Haliotis discus hannai. Fish Sci 67:176-178

Pekkarinen M (1993) Neoplastic disease in the Baltic Macoma balthica (Bivalvia) off the Finnish coast. J Invertebr Pathol 6:138-146

Editorial responsibility: Albert Sparks, Seattle, Washington, USA
Peters EC, Yevich JC, Harshbarger JC, Zaroogian GE (1994) Comparative histopathology of gonadal neoplasms in marine bivalve molluscs. Dis Aquat Org 20:59-76

Phillips RB, Zajicek KD, Ihssen PE, Johnson O (1986) Application of silver staining to the identification of triploid fish cells. Aquaculture 54:313-319

Pich A, Chiusa L, Margaria E (1995) Role of the argyrophilic nucleolar organizer regions (AgNORs) in tumor detection and prognosis. Cancer Detect Prev 19:282-291

Pich A, Chiusa L, Margaria E (2000) Prognostic relevance of AgNORs in tumor pathology. Micron 31:133-141

Pich A, Margaria EL, Chiusa L (2002) Significato delle AgNOR in patologia tumorale. Pathologica 94:2-9

Thiriot-Quiévreux C (2002) Review of the literature on bivalve cytogenetics in the last ten years. Cah Biol Mar 43:17-26

Thiriot-Quiévreux C, Ayraud N (1982) Les caryotypes de quelques espèces de bivalves et de gastéropodes marins. Mar Biol 70:165-172

Thiriot-Quiévreux C, Wolowicz M (1996) Etude caryologique d'une néoplasie branchiale chez Macoma balthica (Mollusca, Bivalvia). CR Acad Sci Sér III Sci Vie 319: 887-892

Thiriot-Quiévreux C, Wolowicz M (2001) Chromosomal study of spatial variation of the prevalence of a gill neoplasia in Macoma balthica from the Gulf of Gdansk (Baltic Sea). Ophelia 54:75-81

Trerè D (2000) AgNOR staining and quantification. Micron 31:127-131

Villalba A, Carballal MJ, Lopez C (2001) Disseminated neoplasia and large foci indicating heavy haemocytic infiltrations in cockles Cerastoderma edule from Galicia (NW Spain). Dis Aquat Org 46:213-216

Zergeroglu S, Aksakal O, Demitturk F, Gokmen O (2001) Prognostic importance of the nucleolar organizer region score in ovarian epithelial tumors. Gynecol Obstet Investig 51:60-63

Submitted: March 12, 2003; Accepted: June 17, 2003

Proofs received from author(s): August 29, 2003 